\title{
Growth and Economic Assessment of Wheat under Tillage and Nitrogen Levels in Rice-Wheat System
}

\author{
Rafi Qamar $^{1^{*}}$, Ehsanullah $^{2}$, Abdul Rehman ${ }^{1}$, Amjed Ali $^{1}$, Abdul Ghaffar ${ }^{3}$, Athar Mahmood ${ }^{1}$, \\ Hafiz Muhammad Rashad Javeed ${ }^{4}$, Mudassir Aziz ${ }^{1}$ \\ ${ }^{1}$ Department of Agronomy, University College of Agriculture, University of Sargodha, Sargodha, Pakistan; ${ }^{2}$ Department of Agron- \\ omy, Faculty of Agriculture, University of Agriculture, Faisalabad, Pakistan; ${ }^{3}$ Plant Physiology Section, Ayub Agricultural Research \\ Institute, Faisalabad, Pakistan; ${ }^{4}$ Department of Environmental Sciences, NFC Institute of Engineering and Technology, Multan, Paki- \\ stan. \\ Email: *rafi1573@gmail.com
}

Received September $1^{\text {st }}, 2013$; revised October $1^{\text {st }}, 2013$; accepted October $15^{\text {th }}, 2013$

Copyright (C) 2013 Rafi Qamar et al. This is an open access article distributed under the Creative Commons Attribution License, which permits unrestricted use, distribution, and reproduction in any medium, provided the original work is properly cited.

\begin{abstract}
Mechanically post-harvest puddled rice field has stubbles that often delay timely planting of winter wheat crop. Zero tillage increased the net return by decreasing the unwise tillage operations and labor charges. Keep in view, a randomized complete block design experiment in a split plot arrangement was conducted with four tillage system [conventional tillage, CT; deep tillage, DT; zero tillage with zone disc tiller, ZDT; and happy seeder, HS] in main plots and five nitrogen levels $\left[0,75,100,125\right.$, and $\left.150 \mathrm{~kg} \cdot \mathrm{ha}^{-1}\right]$ in subplots during 2009 to 2010 and 2010 to 2011 cropping seasons. Results showed that in 2009-10 and 2010-11 grain yield (4.6 Mg.ha ${ }^{-1}$ and $\left.5.7 \mathrm{Mg} \cdot \mathrm{ha}^{-1}\right)$ in DT and (4.5 Mg.ha ${ }^{-1}$ and 5.8 $\mathrm{Mg} \cdot \mathrm{ha}^{-1}$ ) in HS were significantly higher compared with CT and ZDT. Significantly, maximum leaf area index (5.18 and 5.24) and crop growth rate $\left(12.14 \mathrm{~g} \cdot \mathrm{m}^{-2} \cdot \mathrm{d}^{-1}\right.$ and $\left.13.15 \mathrm{~g} \cdot \mathrm{m}^{-2} \cdot \mathrm{d}^{-1}\right)$ were noted in DT. Grain protein $(11.78 \%)$ was significantly higher in DT compared with CT, ZDT, and HS during 2009-10 and 2010-11. Total yield (12.4 Mg.ha ${ }^{-1}$ and $16.4 \mathrm{Mg} \cdot \mathrm{ha}^{-1}$ ) and grain yield (4.9 Mg.ha ${ }^{-1}$ and $6.5 \mathrm{Mg} \cdot \mathrm{ha}^{-1}$ ) at $\mathrm{N}_{125} \mathrm{~kg} \cdot \mathrm{ha}^{-1}$ while grain protein $(13.52 \%)$ at $\mathrm{N}_{150}$ $\mathrm{kg} \cdot \mathrm{ha}^{-1}$ was significantly higher than other nitrogen levels. Maximum LAI (5.08 and 5.51) and crop growth rate (14.68 $\mathrm{g} \mathrm{m}^{-2} \cdot \mathrm{d}^{-1}$ and $15.77 \mathrm{~g} \cdot \mathrm{m}^{-2} \cdot \mathrm{d}^{-1}$ ) were recorded at $\mathrm{N}_{125} \mathrm{~kg} \cdot \mathrm{ha}^{-1}$ respectively. During both the years, all the tillage systems gave higher net return at $\mathrm{N}_{125} \mathrm{~kg} \cdot \mathrm{ha}^{-1}$ during both the growing seasons. DT and HS gave more than $20 \%$ higher yield and improved crop growth of irrigated wheat than CT and ZDT. Happy seeder provides immediate, identifiable, and demonstrable economic benefits by reducing production costs.
\end{abstract}

Keywords: Leaf Area Index; Grain Yield; Protein Content; Net Return; Wheat

\section{Introduction}

Rice-wheat cropping system has substantial role in world food security and provides about $8 \%$ staple grain to the world's population (Timsina and Connor) [1]. In South Asia, the area under rice-wheat cropping system is about 13.5 million hectares, which has meaningful role in food self-sufficiency (Saharawat et al.) [2]. In rice-wheat system, wheat yield is stagnant due to long-term use of conventional management practices, which exerts destructive effects on soil productivity and farm economics in post-harvest paddy field (Duxbury et al.) [3].

However, conventional tillage system reduces the soil

${ }^{*}$ Corresponding author. compaction and enhances the nutrient stratification (Boydas and Turgut) [4]. Subsurface soil compaction by conventional tillage decreased both the nutrient and water use efficiencies and reduced the root growth of following wheat (Qamar et al.) [5]. Deep plowing breaks the sub-surface hard pan and improves the wheat crop growth and yield by increasing the rooting depth (Chaudhary et al.) [6]. No doubt, deep tillage has good response on crop yield due to fine seedbed preparation but it is expansive in terms of fuel and time (Qin et al.) [7]. Zero till wheat cultivation after rice is the most productive and resource-conserving technology (Erenstein $e t$ al., 2007) [8]; Erenstein and Laxmi) [9], which has been successfully practiced on more than 111 million hectare 
worldwide (Derpsch et al.) [10]. It significantly decreases farming costs, soil erosion and improves ecosystem than conventional plowing (Sundermeier et al.) [11]. Continuous use of zero tillage practice considerably improves the net income of crop (Verch et al.) [12]. Moreover, zero tillage system gives equal to or even higher wheat grain yield than conventional plowed field (Qamar et al.) [5].

In rice-wheat cropping areas, different tillage systems are used for handling rice residues that have substantial effect on wheat yield and net profitability. Deep residues incorporation by disc plough or by mould-board plough is a better choice for effective disposal of residue and gives higher yield and net farm returns. Zero tillage recorded grain yield at par with deep tillage and higher than conventional tillage (Qamar et al.) [5] while net returns was higher than deep and conventional tillage systems (Kumar et al.) [13]. Zero tillage growers are the main beneficiaries by raising their farm income about US\$100 per hectare and cost-saving effect is about US\$52 per hectare due to reduction in tractor time and fuel for wheat seedbed preparation (Erenstein, 2009) [14]. It enhances the farmer's ability to practice in equitable, cost-efficient and sustainable way (Ladha et al.) [15]. The popularity of zero tillage is rapidly increasing due to its economic benefits. Zero tillage farmers gain net income of about US\$93, whereas conventional growers get about US\$74 per acre. Zero tillage gives an additional net benefit of US\$19 over the conventional tillage (Directorate General Agriculture, (DGA) [16]. Zero tillage minimized the energy consumption, workloads of farm operations in the range of $15 \%-50 \%$, and enhanced the energetic productivity by $25 \%-100 \%$ (Garcua-Torres) [17]. Landers [18] reported that if timing of entry and cost of ZT compared with the heavy tillage machinery, the farmers preferred to purchase ZT drills.

In rice-wheat cropping systems, nitrogen immobilization is a more critical problem in alternate year in ricewheat crop production systems due to high values $\mathrm{C}: \mathrm{N}$ of crop residues (Weisz et al.) [19]. In NT, crop residues remain on the soil surface and release of nitrogen slow due to $\mathrm{N}$ immobilization (Schomberg et al.) [20] than conventional tillage systems. If surplus amount of nitrogen fertilizer is applied in ZT field than crop requirement resulting in more leaching and volatilization, that will be greater than $\mathrm{CT}$ field losses (Cantero-Martıńez et al.) [21]. Current recommendations of $\mathrm{N}$ fertilization developed for continuously plowed systems, which may not be adequate for optimum production of wheat under NT (McConkey et al.) [22]. The main objective of current study was to compare and evaluate the growth, yield and economics of irrigated wheat in rice-wheat production system under conventional tillage, deep tillage, zone disc tiller, and happy seeder with different rates of $\mathrm{N}$ fertilization in a semiarid climate.

\section{Materials and Methods}

\subsection{Study Site}

The study was conducted in a rice-wheat system at the research farm of the University of Agriculture, Faisalabad (latitude $31^{\circ} 26^{\prime} \mathrm{N}$ and $73^{\circ} 06^{\prime} \mathrm{E}$, altitude $185 \mathrm{~m}$ ) in 2009 to 2010 and 2010 to 2011 growing seasons. The soil is the Hafizabad series (fine-loamy, mixed, hyperthermic, Typic Calciargids) and the soil texture is sandy clay loam (Khan, 1986) [23]. Selected chemical and physical characteristics were done before sowing: $\mathrm{pH} 7.7$ \pm 0.1 , electrical conductivity $2.82 \pm 0.3 \mathrm{dS} \cdot \mathrm{m}^{-1}$, soil organic matter content $0.73 \%$, total $\mathrm{N} 0.04 \%$, available phosphorus $62 \mathrm{mg} \cdot \mathrm{kg}^{-1}$, exchangeable potassium 83 $\mathrm{mg} \cdot \mathrm{kg}^{-1}$, and sand $53 \%$, silt $20 \%$ and clay $27 \%$.

\subsection{Experimental Design and Cultural Practices}

A randomized complete block design in split plot arrangement with three replications was carried out in 2009 in a post-harvest puddle rice field. Four tillage systems (conventional tillage, CT; deep tillage, DT; zero tillage with zone disk tiller, ZDT; and happy seeder, HS) were randomized in the main plots while five levels of nitrogen [0, $\left(\mathrm{N}_{0}\right) ; 75\left(\mathrm{~N}_{75}\right) ; 100\left(\mathrm{~N}_{100}\right) ; 125\left(\mathrm{~N}_{125}\right)$; and 150 $\left.\left(\mathrm{N}_{150}\right) \mathrm{kg} \cdot \mathrm{ha}^{-1}\right]$ were applied in $5.4 \mathrm{~m}$ by $8 \mathrm{~m}$ as subplots. Wheat (var. Sahar 2006) was planted @ rate of 125 $\mathrm{kg} \cdot \mathrm{ha}^{-1}$ in the third week of November 2009 at $23 \mathrm{~cm}$ apart between rows having 24 rows in each replicated plot. Phosphorous and potash fertilizers were applied at 100 and $60 \mathrm{~kg} \cdot \mathrm{ha}^{-1}$, respectively. A full rate of phosphorous and potash and half of the $\mathrm{N}$ were applied at planting. The remaining half of the $\mathrm{N}$ was applied with first irrigation. Topik $15 \mathrm{WP}$ (Trade name) at $1250 \mathrm{~g}$ powder $\mathrm{ha}^{-1}$ was applied to control weeds.

\subsection{Calculation of Net Return (Rs. $\mathrm{ha}^{-1}$ ) of Wheat}

Net return was determined by subtracting the total cost of production from the gross income of each treatment (CIMMYT 1988) [24].

Net income $=$ Gross income - Cost of production

\section{Statistical Analysis}

Data were analyzed statistically using SAS (SAS Institute) [25]. The effects of tillage and $\mathrm{N}$ levels their interaction were evaluated by the least significant difference (LSD) test at $\mathrm{p} \leq 0.05$ unless otherwise mentioned.

\section{Results and Discussion}

\subsection{Tillage and Nitrogen Fertilization Effects on Wheat Yield and Protein Content}

Tillage and nitrogen plays a vital role not only in grain 
yield but also in grain quality. Tillage had significant effects on yield and grain protein content of wheat (Table 1). Wheat grain yield in first year of study was significantly higher $\left(4.6 \mathrm{Mg} \cdot \mathrm{ha}^{-1}\right)$ in DT followed by HS $\left(4.5 \mathrm{Mg} \cdot \mathrm{ha}^{-1}\right)$ as compared with CT and ZDT. Grain yield in DT was 17 to $23 \%$ while in HS was 15 to $22 \%$ higher than ZDT and CT. In contrast, significantly higher grain yield was noted $\left(5.8 \mathrm{Mg} \cdot \mathrm{ha}^{-1}\right)$ in $\mathrm{HS}$ followed by
DT (5.7 Mg.ha $\left.{ }^{-1}\right)$ as compared with CT and ZDT during 2010 to 2011 growing season. Similarly, the highest total wheat yields were attained in DT and HS over other treatments in both years. Significantly, maximum grain protein contents were observed in deep tillage and minimum was observed in zero tillage systems (Happy seeder and zone disc tiller) during both the growing seasons.

In both the years of study, nitrogen fertilization had

Table 1. Tillage systems and nitrogen levels interaction on total and grain yield and protein content of irrigated wheat in Faisalabad, Pakistan (data of 2009-10 and 2010-11 growing season).

\begin{tabular}{|c|c|c|c|c|c|c|c|}
\hline \multirow[t]{2}{*}{ Tillage system } & \multirow[t]{2}{*}{ Nitrogen level $\left(\mathrm{kg} \cdot \mathrm{ha}^{-1}\right)$} & \multicolumn{2}{|c|}{ Total yield $\left(\mathrm{Mg} \cdot \mathrm{ha}^{-1}\right)$} & \multicolumn{2}{|c|}{ Grain yield $\left(\mathrm{Mg} \cdot \mathrm{ha}^{-1}\right)$} & \multicolumn{2}{|c|}{ Protein content $(\%)$} \\
\hline & & $2009-10$ & $2010-11$ & $2009-10$ & $2010-11$ & $2009-10$ & 2010-11 \\
\hline & 0 & $5.9 \mathrm{~d}^{\Psi}$ & $8.5 \mathrm{c}$ & $3.0 \mathrm{c}$ & $3.3 \mathrm{~d}$ & $8.40 \mathrm{e}$ & $8.41 \mathrm{e}$ \\
\hline & 75 & $10.4 \mathrm{c}$ & $13.7 \mathrm{~b}$ & $4.1 \mathrm{~b}$ & $5.4 \mathrm{c}$ & $11.57 \mathrm{~d}$ & $11.58 \mathrm{~d}$ \\
\hline & 100 & $11.6 \mathrm{~b}$ & $15.6 \mathrm{a}$ & $4.6 \mathrm{a}$ & $6.2 b$ & $12.25 \mathrm{c}$ & $12.25 \mathrm{c}$ \\
\hline & 125 & $12.4 \mathrm{a}$ & $16.4 \mathrm{a}$ & $4.9 \mathrm{a}$ & $6.5 \mathrm{a}$ & $12.96 \mathrm{~b}$ & $12.98 \mathrm{~b}$ \\
\hline & 150 & $11.4 \mathrm{~b}$ & $14.8 \mathrm{ab}$ & $4.6 \mathrm{ab}$ & $6.1 b$ & $13.52 \mathrm{a}$ & $13.52 \mathrm{a}$ \\
\hline & & \multicolumn{6}{|c|}{ Tillage $\times \mathrm{N}$ interaction } \\
\hline \multirow[t]{6}{*}{$\mathrm{CT}$} & 0 & 5.4 & 7.8 & 2.0 & 3 & 8.40 & 8.42 \\
\hline & 75 & 9.8 & 13.5 & 3.8 & 5.3 & 11.56 & 11.58 \\
\hline & 100 & 10 & 15.3 & 3.9 & 6 & 12.26 & 12.26 \\
\hline & 125 & 10.3 & 16.2 & 4.1 & 6.4 & 12.96 & 12.98 \\
\hline & 150 & 9.5 & 14.1 & 3.8 & 5.6 & 13.52 & 13.52 \\
\hline & & $9 C^{*}$ & $13.4 \mathrm{~A}$ & $3.5 \mathrm{~B}$ & $5.3 \mathrm{~B}$ & 11.74B & $11.75 \mathrm{~B}$ \\
\hline \multirow[t]{6}{*}{ DT } & 0 & 4.9 & 9.2 & 1.9 & 3.6 & 8.45 & 8.46 \\
\hline & 75 & 11.6 & 13.7 & 4.6 & 5.4 & 11.59 & 11.61 \\
\hline & 100 & 13.2 & 15.8 & 5.3 & 6.3 & 12.29 & 12.29 \\
\hline & 125 & 14.5 & 16.6 & 5.8 & 6.6 & 13.01 & 13.02 \\
\hline & 150 & 13.7 & 16.2 & 5.5 & 6.5 & 13.55 & 13.54 \\
\hline & & $11.6 \mathrm{~A}$ & $14.3 \mathrm{~A}$ & $4.6 \mathrm{~A}$ & $5.7 \mathrm{~A}$ & $11.78 \mathrm{~A}$ & $11.78 \mathrm{~A}$ \\
\hline \multirow[t]{6}{*}{ ZDT } & 0 & 6 & 8 & 2.4 & 3.1 & 8.37 & 8.38 \\
\hline & 75 & 9 & 13.4 & 3.6 & 5.3 & 11.55 & 11.56 \\
\hline & 100 & 10.8 & 15.4 & 4.3 & 6.2 & 12.22 & 12.22 \\
\hline & 125 & 11.5 & 15.9 & 4.6 & 6.3 & 12.93 & 12.95 \\
\hline & 150 & 10 & 14.3 & 3.9 & 5.7 & 13.49 & 13.50 \\
\hline & & $9.4 \mathrm{~B}$ & $13.4 \mathrm{~A}$ & $3.8 \mathrm{~B}$ & $5.3 \mathrm{~B}$ & $11.71 \mathrm{C}$ & $11.72 \mathrm{C}$ \\
\hline \multirow[t]{7}{*}{ HS } & 0 & 7.3 & 9 & 2.9 & 3.5 & 8.38 & 8.39 \\
\hline & 75 & 11 & 14 & 4.4 & 5.6 & 11.56 & 11.57 \\
\hline & 100 & 12.4 & 15.9 & 5.0 & 6.4 & 12.23 & 12.23 \\
\hline & 125 & 13.3 & 17 & 5.3 & 6.8 & 12.94 & 12.96 \\
\hline & 150 & 12.7 & 16.5 & 5.1 & 6.6 & 13.50 & 13.51 \\
\hline & & $11.4 \mathrm{~A}$ & $14.5 \mathrm{~A}$ & $4.5 \mathrm{~A}$ & $5.8 \mathrm{~A}$ & $11.72 \mathrm{BC}$ & $11.73 \mathrm{C}$ \\
\hline & Tillage $\times$ Nitrogen & 1.1 & ns & $\mathrm{ns}$ & 0.3 & ns & ns \\
\hline
\end{tabular}

$\mathrm{CT}=$ Conventional tillage. DT $=$ Deep tillage. $\mathrm{ZDT}=$ Zone disc tiller (zero tillage drill). HS $=$ Happy seeder (zero tillage drill). LSD $\mathrm{p} \leq 0.05 ;{ }^{\Psi}=\mathrm{Means}$ separated by lower case letter in each column are not significantly different among nitrogen fertilization rates at $\mathrm{p} \leq 0.05 .{ }^{*}=\mathrm{Means}$ separated by upper case letter in each column are not significantly different among tillage treatments at $\mathrm{p} \leq 0.05$. 
significant influenced on the yield and protein content of irrigated wheat (Table 1). During both the years of study, significantly higher wheat grain yield was recorded at $\mathrm{N}_{125} \mathrm{~kg} \cdot \mathrm{ha}^{-1}$ that was $49,16,4$ and $4 \%$ greater than $\mathrm{N}_{0}$, $\mathrm{N}_{75}, \mathrm{~N}_{100}$ and $\mathrm{N}_{150} \mathrm{~kg} \cdot \mathrm{ha}^{-1}$, respectively. Similarly, higher total yield was in $\mathrm{N}_{125} \mathrm{~kg} \cdot \mathrm{ha}^{-1}$ that was 50, 16, 5 and 5\% greater than $\mathrm{N}_{0}, \mathrm{~N}_{75}, \mathrm{~N}_{100}$ and $\mathrm{N}_{150} \mathrm{~kg} \cdot \mathrm{ha}^{-1}$, respectively in both the years. In 2009 to 2010 and 2010 to 2011 growing years, maximum grain protein content was observed when wheat crop fertilized with nitrogen @ 150 $\mathrm{kg} \cdot \mathrm{ha}^{-1}$ followed by $\mathrm{N}_{125} \mathrm{~kg} \cdot \mathrm{ha}^{-1}$ and minimum was noted at $\mathrm{N}_{0} \mathrm{~kg} \cdot \mathrm{ha}^{-1}$.

In the 2009 to 2010 growing season, tillage $\times$ nitrogen interaction significantly influenced total yield while grain yield in second year and grain protein content remained non-significant during both the growing seasons. However, deep tillage and happy seeder under $\mathrm{N}_{125} \mathrm{~kg} \cdot \mathrm{ha}^{-1}$ produced significantly higher yield of wheat over other tillage $\times$ nitrogen combinations.

Deep tillage produced significantly higher total and grain yield of wheat that was associated with better seedbed preparation, higher soil porosity and greater water and nutrient availability (Khan et al.) [26] while lower yield under CT was due to subsurface soil compaction which may have hindered root growth (Lopez-Bellido et al., 2007) [27]. In several studied, consistently higher yields in HS and DT than in CT were reported (Sip et al.) [28]. Significantly higher grain yield in HS was observed due to cooler and maximum soil moisture content than CT and DT, which improved water use efficiency of crops (Su et al.) [29]. Happy seeder produced higher grain yield than zone disc tiller in both the year due to seed cover by rice straw (Morris et al.) [30] which reduced moisture evaporation and improved seed-to-soil contact. In case of zone disc tiller, furrow opener was not covered by rice straw that decreased seed germination and resulted in lower yield (Tessir et al.) [31]. Deep tillage had longer root length due to deep plowing that increased the nutrient and water use efficiency (Qamar et al.) [5] which help in increasing the grain protein content (Cociu and Alionte) [32]. However, lower grain protein content in zero tillage was due to higher soil bulk density and penetration resistance, which reduced the root length and ultimately lower the protein content (Vita et al.) [33]. Significantly, higher grain protein content was also reported due to better root growth and nutrient use efficiency in zero tillage (Coventry et al.) [34].

Nitrogen fertilization had significant effects on the yield and protein content during both the years of study. It is reported that total and grain yields increased by increasing nitrogen fertilization, but excess of nitrogen often decreased the yields because other yield compo- nents of wheat are decreased with an associated decrease in vegetative growth (Khan et al.) [35]. Similarly, Tavakoli and Oweis [36] reported that with irrigation, the response of winter wheat to nitrogen significantly increased up to $60 \mathrm{~kg} \cdot \mathrm{ha}^{-1}$. Both the years of study at higher nitrogen levels higher grain protein was noted. Hussain et al. [37] reported that nitrogen fertilizer levels affect the protein contents and increased by increasing the nitrogen rates. The higher water and nutrient use efficiency in deep tillage and in happy seeder at nitrogen fertilization $125 \mathrm{~kg} \cdot \mathrm{ha}^{-1}$ was favored to produce higher yields (Qamar et al. [5]. Grain protein content was not affected by increasing the total and grain yield during second year of study.

\subsection{Tillage and Nitrogen Fertilization Effects on Wheat Growth}

Leaf area index (LAI) and crop growth rate (CGR) are the basic physiological parameters, which showed the size of crop assimilates and rate of dry matter accumulation per unit area respectively. Significant effect of different tillage systems and nitrogen fertilization on LAI and CGR were found in both the growing seasons (Figures 1-4). Leaf area index of tillage system in both the growing seasons (Figure 1) line curve increased gradually and attained the peak at 75 days after sowing (DAS). After 75 days, the line started to decreased and reached lower point at 135 DAS. The line curve of deep tillage remained above than the other tillage systems during both the growing seasons. Maximum leaf area index (5.18 and 5.24) was attained at 75 days by deep tillage followed by happy seeder and minimum was noted in conventional tillage. In both the growing years, CGR (Figure 3) of tillage system increased and attained maximum level at 75 DAS. After 75 days, it decreased slowly up to 95 DAS then sharp decline up to 115 DAS. After 115 days, CGR decreased but comparatively at lower rate. The line curve of deep tillage remained higher than conventional tillage, zone disc tiller and happy seeder throughout the growing seasons. Deep tillage in both years of study produced the maximum crop growth rate of $12.14 \mathrm{~g} \cdot \mathrm{m}^{-2} \cdot \mathrm{d}^{-1}$ and $13.15 \mathrm{~g} \cdot \mathrm{m}^{-2} \cdot \mathrm{d}^{-1}$ followed by happy seeder and minimum CGR was noted in conventional tillage.

During both the years (Figure 2) leaf area index of wheat crop was maximum when fertilized with $\mathrm{N}_{125}$ $\mathrm{kg} \cdot \mathrm{ha}^{-1}$ followed by $\mathrm{N}_{100} \mathrm{~kg} \cdot \mathrm{ha}^{-1}$ and minimum was observed in $\mathrm{N}_{0} \mathrm{~kg} \cdot \mathrm{ha}^{-1}$. The line curve of leaf area index at $\mathrm{N}_{125} \mathrm{~kg} \cdot \mathrm{ha}^{-1}$ remained above of $\mathrm{N}_{150}, \mathrm{~N}_{100}, \mathrm{~N}_{75}$ and $\mathrm{N}_{0}$ $\mathrm{kg} \cdot \mathrm{ha}^{-1}$ throughout the growing seasons. In both the years, maximum LAI of 5.08 and 5.51 were observed at $\mathrm{N}_{125}$ $\mathrm{kg} \cdot \mathrm{ha}^{-1}$. The line curve of crop growth rate at $\mathrm{N}_{125}$ $\mathrm{kg} \cdot \mathrm{ha}^{-1}$ (Figure 4) remained higher during both the growing seasons and attained maximum crop growth rate 

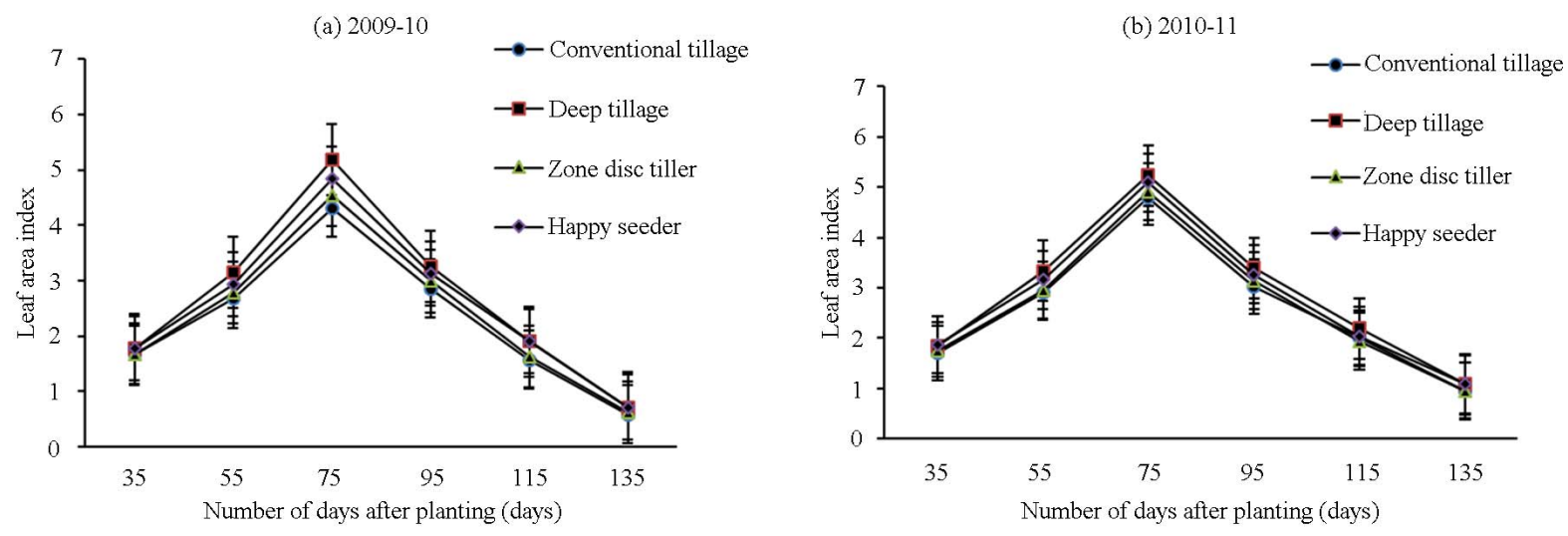

Figure 1. Leaf area index as affected by different tillage systems.
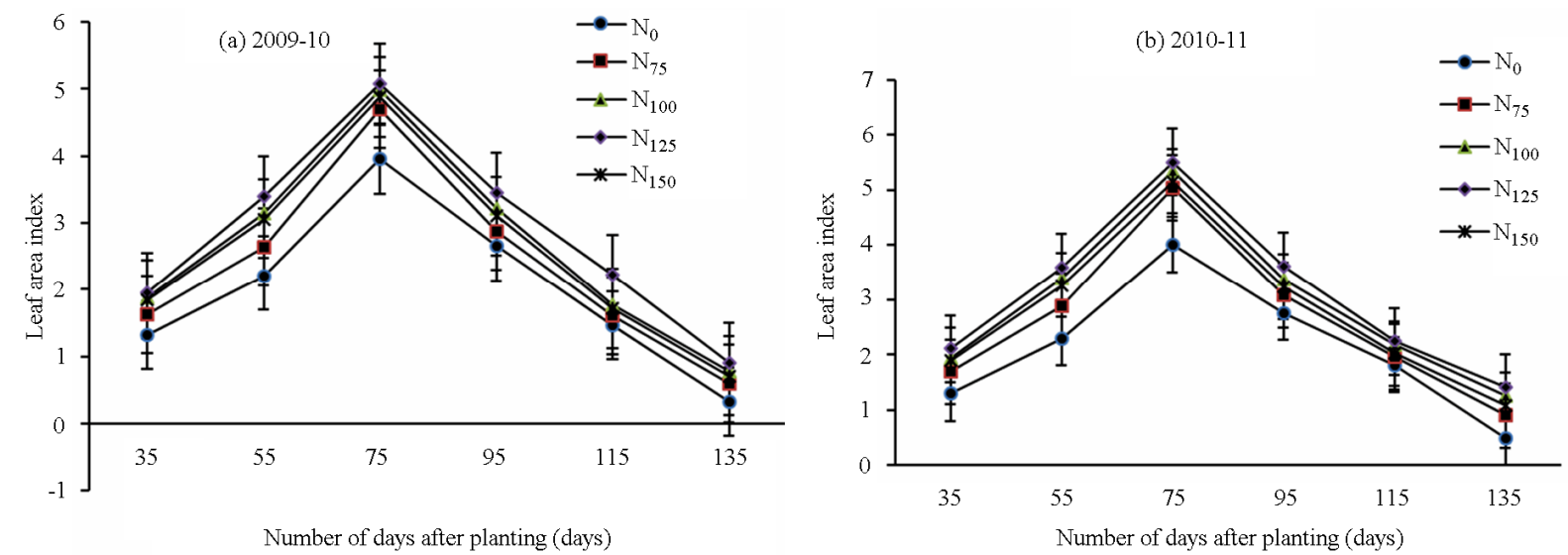

Figure 2. Leaf area index as affected by different nitrogen levels.
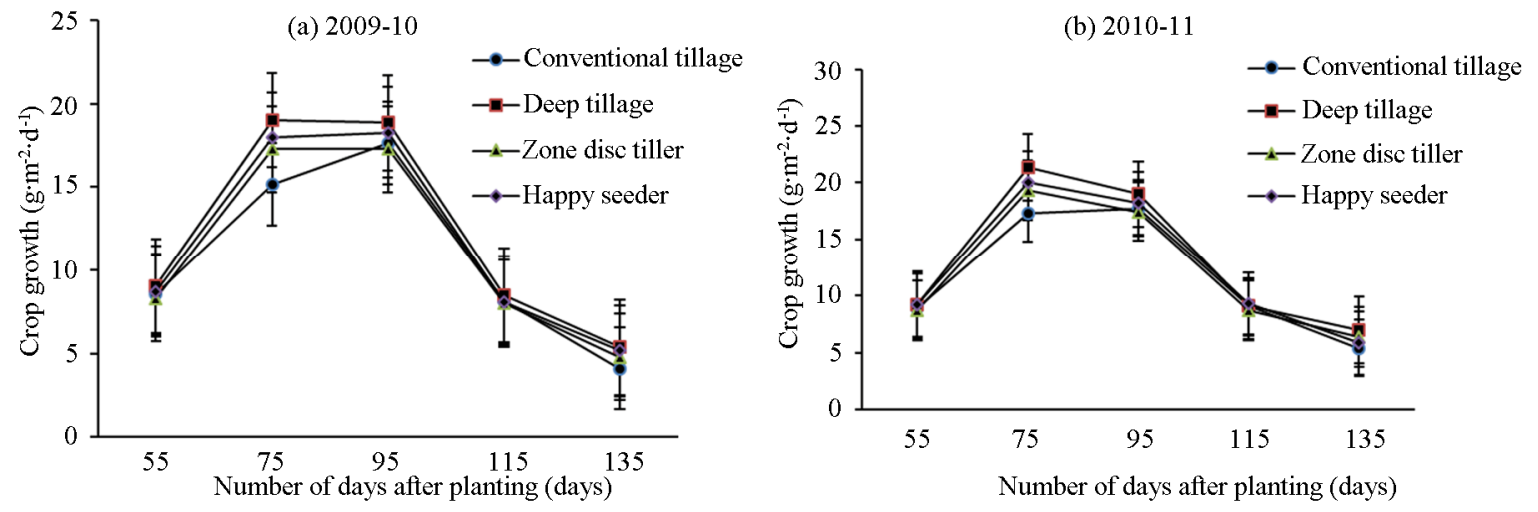

Figure 3. Crop growth rate as affected by different tillage systems.

of $14.68 \mathrm{~g} \cdot \mathrm{m}^{-2} \cdot \mathrm{d}^{-1}$ and $15.77 \mathrm{~g} \cdot \mathrm{m}^{-2} \cdot \mathrm{d}^{-1}$, followed by $\mathrm{N}_{100}$ $\mathrm{kg} \cdot \mathrm{ha}^{-1}$ and minimum was noted at $\mathrm{N}_{0} \mathrm{~kg} \cdot \mathrm{ha}^{-1}$. Decline in CGR at 75 days was less in 2009-10 while in the succeeding year this decline was sharp which might be attributes to variation in climatic conditions.

In first year mean maximum temperature from 75 DAS to 95 DAS was increased while in second year the mean maximum temperature was decreased from 75 DAS to 95 DAS. It is clear that during both the growing seasons there was significant difference in leaf area index and crop growth rate not only among tillage systems but also between the various nitrogen levels. In both the growing seasons, all the tillage systems gave maximum crop growth parameters @ $\mathrm{N}_{125} \mathrm{~kg} \cdot \mathrm{ha}^{-1}$ followed by $\mathrm{N}_{100}$ $\mathrm{kg} \cdot \mathrm{ha}^{-1}$ and minimum was noted at $\mathrm{N}_{0} \mathrm{~kg} \cdot \mathrm{ha}^{-1}$. Significantly higher LAI and CGR in deep tillage was due to fine seedbed and longer root length that favored nutrient and water use efficiency, which positively affected the 

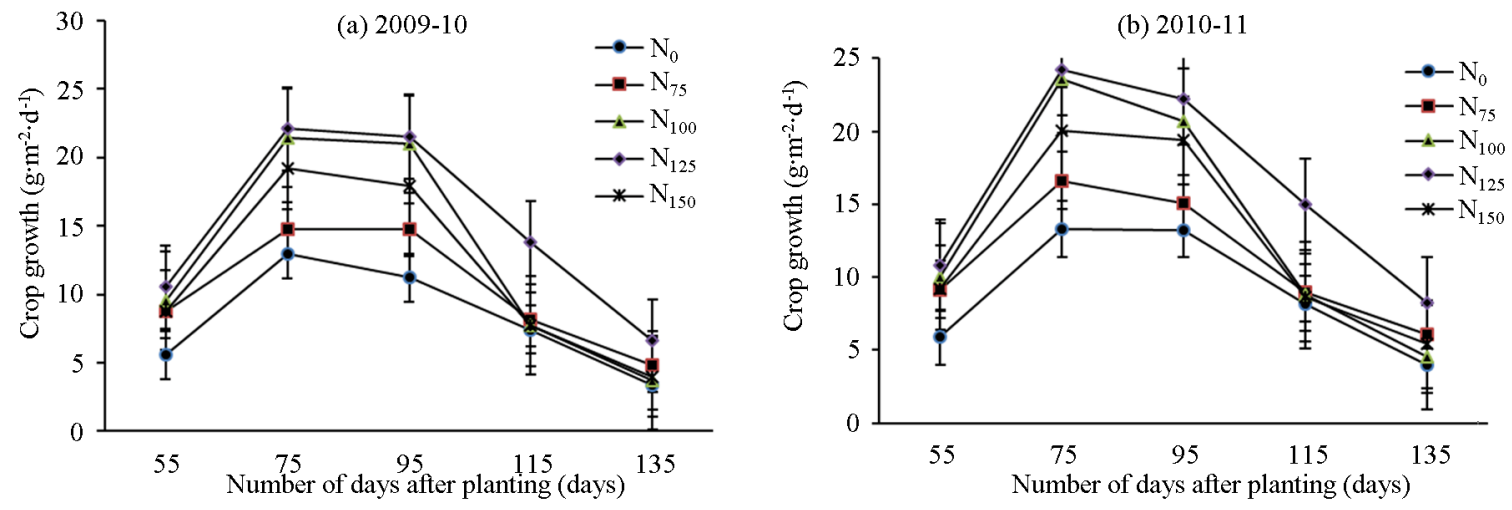

Figure 4. Crop growth rate as affected by different nitrogen levels.

Table 2. Effect of different tillage systems and nitrogen levels on net return of irrigated wheat (data of 2009-2010 and 2010-2011 growing seasons).

\begin{tabular}{|c|c|c|c|c|c|c|c|c|c|}
\hline \multirow{2}{*}{\multicolumn{2}{|c|}{ Treatment }} & \multicolumn{2}{|c|}{ Gross income (Rs. ha $\left.{ }^{-1}\right)$} & \multicolumn{2}{|c|}{ Variable cost $\left(\right.$ Rs. $\left.\mathrm{ha}^{-1}\right)$} & \multicolumn{2}{|c|}{ Total cost (Rs. ha $\left.{ }^{-1}\right)$} & \multicolumn{2}{|c|}{ Net Return (Rs. ha $\left.{ }^{-1}\right)$} \\
\hline & & 2009-10 & 2010-11 & 2009-10 & 2010-11 & 2009-10 & 2010-11 & 2009-10 & 2010-11 \\
\hline \multirow{5}{*}{ CT: Conventional tillage } & $\mathrm{N}_{0}$ : No nitrogen & 61100 & 90450 & 6531 & 9809 & 80351 & 83692 & -19251 & 6746 \\
\hline & $\mathrm{N}_{75}: 75 \mathrm{~kg} \cdot \mathrm{N} \cdot \mathrm{ha}^{-1}$ & 114250 & 158675 & 15434 & 21563 & 89242 & 95453 & 24996 & 63217 \\
\hline & $\mathrm{N}_{100}: 100 \mathrm{~kg} \cdot \mathrm{N} \cdot \mathrm{ha}^{-1}$ & 117025 & 179700 & 16653 & 25144 & 90479 & 99039 & 26552 & 80661 \\
\hline & $\mathrm{N}_{125}: 125 \mathrm{~kg} \cdot \mathrm{N} \cdot \mathrm{ha}^{-1}$ & 122175 & 191200 & 18271 & 27813 & 92085 & 101708 & 30084 & 89492 \\
\hline & $\mathrm{N}_{150}: 150 \mathrm{~kg} \cdot \mathrm{N} \cdot \mathrm{ha}^{-1}$ & 113050 & 167000 & 18376 & 26688 & 92184 & 100583 & 20854 & 66417 \\
\hline \multirow{5}{*}{ DT: Deep tillage } & $\mathrm{N}_{0}$ : No nitrogen & 57125 & 107900 & 6199 & 17756 & 80025 & 85651 & -22894 & 22249 \\
\hline & $\mathrm{N}_{75}: 75 \mathrm{~kg} \cdot \mathrm{N} \cdot \mathrm{ha}^{-1}$ & 137250 & 161050 & 18046 & 21896 & 91855 & 95779 & 45384 & 65259 \\
\hline & $\mathrm{N}_{100}: 100 \mathrm{~kg} \cdot \mathrm{N} \cdot \mathrm{ha}^{-1}$ & 157475 & 187625 & 21237 & 26118 & 95051 & 100018 & 62418 & 87612 \\
\hline & $\mathrm{N}_{125}: 125 \mathrm{~kg} \cdot \mathrm{N} \cdot \mathrm{ha}^{-1}$ & 172550 & 196350 & 23829 & 28478 & 97637 & 102361 & 74901 & 93977 \\
\hline & $\mathrm{N}_{150}: 150 \mathrm{~kg} \cdot \mathrm{N} \cdot \mathrm{ha}^{-1}$ & 163425 & 193175 & 23910 & 29633 & 97736 & 103522 & 65695 & 89647 \\
\hline \multirow{5}{*}{ ZT: Zone disc tiller } & $\mathrm{N}_{0}$ : No nitrogen & 71400 & 93225 & 7838 & 10118 & 73658 & 76018 & -2258 & 17212 \\
\hline & $\mathrm{N}_{75}: 75 \mathrm{~kg} \cdot \mathrm{N} \cdot \mathrm{ha}^{-1}$ & 107500 & 158275 & 14769 & 21564 & 80589 & 87453 & 26911 & 70816 \\
\hline & $\mathrm{N}_{100}: 100 \mathrm{~kg} \cdot \mathrm{N} \cdot \mathrm{ha}^{-1}$ & 128125 & 184050 & 17959 & 25809 & 83785 & 91692 & 44346 & 92346 \\
\hline & $\mathrm{N}_{125}: 125 \mathrm{~kg} \cdot \mathrm{N} \cdot \mathrm{ha}^{-1}$ & 136850 & 187625 & 19909 & 27481 & 85718 & 93381 & 51121 & 94249 \\
\hline & $\mathrm{N}_{150}: 150 \mathrm{~kg} \cdot \mathrm{N} \cdot \mathrm{ha}^{-1}$ & 116625 & 170175 & 18685 & 27020 & 84511 & 92909 & 32120 & 77260 \\
\hline \multirow{5}{*}{ ZT: Happy seeder } & $\mathrm{N}_{0}$ : No nitrogen & 86475 & 104325 & 9476 & 11424 & 75290 & 77325 & 11179 & 27006 \\
\hline & $\mathrm{N}_{75}: 75 \mathrm{~kg} \cdot \mathrm{N} \cdot \mathrm{ha}^{-1}$ & 131300 & 166600 & 17382 & 22538 & 83202 & 88433 & 48098 & 78167 \\
\hline & $\mathrm{N}_{100}: 100 \mathrm{~kg} \cdot \mathrm{N} \cdot \mathrm{ha}^{-1}$ & 148750 & 190400 & 20263 & 26450 & 86071 & 92345 & 62667 & 98055 \\
\hline & $\mathrm{N}_{125}: 125 \mathrm{~kg} \cdot \mathrm{N} \cdot \mathrm{ha}^{-1}$ & 157875 & 201900 & 22190 & 29119 & 88004 & 95015 & 69865 & 106886 \\
\hline & $\mathrm{N}_{150}: 150 \mathrm{~kg} \cdot \mathrm{N} \cdot \mathrm{ha}^{-1}$ & 151525 & 196350 & 22604 & 29965 & 88430 & 95848 & 63101 & 100490 \\
\hline
\end{tabular}

Wheat grain price $(2009-10$ and $2010-11)=$ Rs. 950 per $40 \mathrm{~kg}$. Wheat straw price $=$ Rs. 160 per $40 \mathrm{~kg}$. Threshing charges $=5.5 \mathrm{~kg}$ per $40 \mathrm{~kg}$. Wheat grain price $=$ Rs. 23.75 per kg. Conventional and deep tillage charges $=11500 \mathrm{ha}^{-1}$. Zone disc tiller and happy seeder charges $=3500$ ha ${ }^{-1}$. Urea charges $(2009-10)=$ Rs. 875 per bag. Urea charges $(2010-11)=$ Rs. 1250 per bag. Application charges $=$ Rs. 250. Total permanent cost $(2009-10)=$ Rs. 62320 . Total permanent cost $(2010-11)=$ Rs. 62395 .

plant growth (Kosmas et al.) [38]. In case of zero tillage (Happy seeder), produced higher growth parameter than conventional tillage was due to moisture and nutrient availability near the soil surface that enhanced the growth. Crop growth parameter like leaf area index and crop growth rate were increased by increasing the nitro- gen levels because nitrogen fertilizer boost up the plant growth up to certain level and produced more vegetative growth (Warraich et al.) [39]. Moreover, significant difference in wheat growth and yields between growing seasons was due to the variations in air temperatures, amount of rainfall and relative humidity. The weather of 
the 2010 to 2011 growing season was more favorable to irrigated wheat growth and yield compared to the weather conditions in 2009 to 2010 growing season.

\subsection{Tillage and Nitrogen Fertilization Effects on Wheat Economics}

Economic analysis is essential to check the profitability and net return of the system. Farmers are more interested in variable costs and economic return of newly introduced enterprises. Economic analysis assist researcher to plan their research for detail investigation and make decision, which provides base for recommendations to the farmers. The variability in net return is more important than variability in crop yield (Jabran et al.) [40]. Net return was calculated during both the years (2009-10 and 2010-11) (Table 2). In second growing season, the environment during the whole crop period was good and timely rainfall at critical stages well supported the growth of wheat. The yield in the second year 2010-11 (Table 1) was more than in year 2009-10. During both the years conventional tillage (Rs. 30084 and Rs. 89492), deep tillage (Rs. 74901 and Rs. 93977), zone disc tiller (Rs. 51121 and Rs. 94249) and happy seeder (Rs. 69865 and Rs. 106889) gave maximum net return at $\mathrm{N}_{125}$ $\mathrm{kg} \cdot \mathrm{ha}^{-1}$. All the tillage systems gave minimum net return at control during both the years. Wheat crop planted with zero tillage (Happy seeder and zone disc tiller) gave higher net return than conventional methods of sowing during both the growing seasons. In zero tillage, low fixed cost of production and higher grain yield with respect to conventional tillage system gave maximum net return at all nitrogen levels. The yields of all the combinations were statistically at par but the difference in net return was due to less cost of production in zero tillage as compared with conventional method. In rice-wheat cropping system, zero tillage were produced higher grain yield than conventional tillage and the primarily cost saving technology, which gave maximum net return (Erienstien et al., 2008) [41].

\section{Conclusion}

Deep tillage and happy seeder (zero tillage) gave more than $20 \%$ higher yield than conventional tillage and zone disc tiller (zero tillage) and improved crop growth of irrigated wheat after puddle rice. However, deep tillage along with $\mathrm{N}_{150} \mathrm{~kg} \cdot \mathrm{ha}^{-1}$ had greater grain protein content than any other tillage systems and nitrogen levels. The higher crop yield in zero tillage (happy seeder) than conventional method of sowing was due to timely crop establishment that resulted in form of improved crop yield. Moreover, happy seeder (zero tillage) provides immediate, identifiable, and demonstrable economic benefits by reducing production costs. All the tillage system gave the maximum net return at $\mathrm{N}_{125} \mathrm{~kg} \cdot \mathrm{ha}^{-1}$. The maximum net returns was noted in zero tillage that was due to economic superiority over conventional method of sowing.

\section{REFERENCES}

[1] J. Timsina and D. J. Connor, "Productivity and Management of Rice-Wheat Cropping Systems: Issues and Challenges," Field Crops Research, Vol. 69, No. 2, 2001, pp. 93-132. http://dx.doi.org/10.1016/S0378-4290(00)00143-X

[2] Y. S. Saharawat, B. Singh, R. K. Malik, J. K. Ladha, M. Gathala, M. L. Jat and V. Kumar, "Evaluation of Alternative Tillage and Crop Establishment Methods in a RiceWheat Rotation in North Western IGP," Field Crops Research, Vol. 116, No. 3, 2010, pp. 260-267. http://dx.doi.org/10.1016/j.fcr.2010.01.003

[3] J. M. Duxbury, I. P. Abrol, R. K. Gupta and K. F. Bronson, "Analysis of Long-Term Fertility Experiments with Rice-Wheat Rotations in South Asia," In: I. P. Abrol, K. F. Bronson, J. M. Duxbury and R. K. Gupta, Eds., LongTerm Soil Fertility Experiments in Rice-Wheat Cropping Systems, Rice-Wheat Consortium Paper Series 6, RWC, New Delhi, 2000, pp. 7-22.

[4] M. G. Boydas and N. Turgut, "Effect of Tillage Implements and Operating Speeds on Soil Physical Properties and Wheat Emergence," Turkish Journal of Agriculture, Vol. 31, No. 6, 2007, pp. 399-412.

[5] R. Qamar, Ehsanullah, R. Ahmad and M. Iqbal, "Response of Wheat to Tillage and Nitrogen Fertilization in Rice-Wheat System," Pakistan Journal of Agricultural Sciences. Vol. 49, No. 3, 2012, pp. 243-254.

[6] M. R. Chaudhary, R. Khera and C. J. Singh, "Tillage and Irrigation Effects on Growth, Soil Water Depletion and Yield of Wheat Following Rice," Journal of Agricultural Science and Cambridge, Vol. 116, No. 1, 1991, pp. 9-16. http://dx.doi.org/10.1017/S0021859600076097

[7] H.-L. Qin, W.-S. Gao, Y.-C. Ma, L. Ma, C.-M. Yin, Z. Chen and C.-L. Chen, "Effects of Subsoiling on Soil Moisture under No-Tillage for Two Years," Agricultural Science China, Vol. 7, No. 1, 2008, pp. 88-95. http://dx.doi.org/10.1016/S1671-2927(08)60026-7

[8] O. Erenstein, U. Farooq, R. K. Malik and M. Sharif, "Adoption and Impacts of Zero Tillage as a Resource Conserving Technology in the Irrigated Plains of South Asia: Comprehensive Assessment of Water Management in Agriculture," Research Report 19, International Water Management Institute, Colombo, 2007.

[9] O. Erenstein and V. Laxmi, "Zero Tillage Impacts in India's Rice-Wheat Systems," Soil and Tillage Research, Vol. 100, No. 1-2, 2008, pp. 1-14.

http://dx.doi.org/10.1016/j.still.2008.05.001

[10] R. Derpsch, T. Friedrich, A. Kassam and H. W. Li, "Current Status of Adoption of No-Till Farming in the World and Some of Its Main Benefits," International Journal of Agricultural and Biology Engineering, Vol. 3, No. 1, 2010, pp. 1-25. 
[11] A. P. Sundermeier, K. R. Islam, Y. Raut, R. Reeder and W. Dick, "Continuous No-Till Impacts on Biophysical Carbon Sequestration," Soil Science Society of American Journal, Vol. 75, No. 5, 2011, pp. 1779-1788. http://dx.doi.org/10.2136/sssaj2010.0334

[12] G. Verch, H. Kächele, K. Holtl, C. Richter and C. Fuchs, "Comparing the Profitability of Tillage Methods in Northeast Germany," Soil and Tillage Research, Vol. 104, No. 1, 2009, pp. 16-21. http://dx.doi.org/10.1016/j.still.2008.12.012

[13] S. Kumar, D. S. Pandey and N. S. Rana, "Economics and Yield Potential of Wheat (Triticum aestivum L.) as Affected by Tillage, Rice (Oryza sativa L.) Residue and Nitrogen Management Options under Rice-Wheat System," Indian Journal of Agronomy, Vol. 50, No. 2, 2005, pp. 102-105.

[14] O. Erenstein, "Specification Effects in Zero Tillage Survey Data in South Asia's Rice-Wheat Systems," Field Crops Research, Vol. 111, No. 1-2, 2009, pp. 166-172. http://dx.doi.org/10.1016/j.fcr.2008.12.003

[15] J. K. Ladha, J. E. Hill, J. M. Duxbury, R. K. Gupta and R. J. Buresh, "Improving the Productivity and Sustainability of Rice-Wheat Systems: Issues and Impacts," American Society of Agronomy, Crop Science Society of America, Soil Science Society of America, Madison, 2003.

[16] DGA, "Resource Conservation Technology for Enhancing Wheat Productivity. Recommendations for 2000-01," Directorate General Agriculture (Water Management) Punjab, 2000-2001.

[17] L. Garcua-Torres, "Conservation Tillage in Europe: A Needed Challenge," In: CIMMYT and ICARDA, Eds., Conservation Tillage: A Viable Option for Sustainable Agriculture in Central Asia, ICARDA, Almaty, Aleppo, 2000.

[18] J. Landers, "Twenty Five Practical Lessons Learned for Implementation of Zero Tillage in Brazil," In: CIMMYT and ICARDA, Eds., Conservation Tillage: A Viable Option for Sustainable Agriculture in Central Asia, ICARDA, Almaty, Aleppo, 2000.

[19] R. Weisz, C. R. Crozier and R. W. Heiniger, "Optimizing Nitrogen Application Timing in No-Till Soft Red Winter Wheat," Agronomy Journal, Vol. 93, No. 2, 2001, pp. 435-442. http://dx.doi.org/10.2134/agronj2001.932435x

[20] H. H. Schomberg, J. L. Steiner and P. W. Unger, "Decomposition and Nitrogen Dynamics of Crop Residues: Residue Quality and Water Effects," Soil Science Society of American Journal, Vol. 58, No. 2, 1994, pp. 372-381. http://dx.doi.org/10.2136/sssaj1994.03615995005800020 $\underline{019 x}$

[21] C. Cantero-Martínez, P. Angás and J. Lampurlanés, "Growth, Yield and Water Productivity of Barley (Hordeum vulgare L.) Affected by Tillage and Nertilization in Mediterranean Semiarid, Rainfed Conditions of Spain," Field Crops Research, Vol. 84, No. 3, 2003, pp. 341-357. http://dx.doi.org/10.1016/S0378-4290(03)00101-1

[22] B. G. McConkey, B. C. Liang, C. A. Campbell, D. Curtin, A. Moulin, S. A. Brandt and G. P. Lafond, "Crop Rotation and Tillage Impact on Carbon Sequestration in Canadian Prairie Soils," Soil and Tillage Research, Vol. 74,
No. 1, 2003, pp. 81-90

http://dx.doi.org/10.1016/S0167-1987(03)00121-1

[23] G. S. Khan, "Need for International Crosschecking and Correlation in Soil Analysis for International Classification Systems," In: Proceedings of the Twelfth International Forum on Soil Taxonomy and Agro-Technology Transfer: Soil Survey of Pakistan, Vol. 1, Director General, Soil Survey of Pakistan, Lahore, 1986, pp. 276-293.

[24] International Maize and Wheat Improvement Center (CIMMYT), "From Agronomic Data to Farmers Recommendations: An Economics Training Manual," Completely Revised Edition, CIMMYT, Mexico D.F., 1988.

[25] SAS Institute, "SAS Online Doc 9.13," SAS Institute, Inc., Cary, 2008.

[26] F. U. H. Khan, A. R. Tahir and I. J. Yule, "Intrinsic Implication of Different Tillage Practices on Soil Penetration Resistance and Crop Growth," International Journal of Agriculture and Biology, Vol. 3, No. 1, 2001, pp. 2326.

[27] R. J. López-Bellido, L. López-Bellido, J. Benítez-Vega and F. J. López-Bellido, "Tillage System, Preceding Crop, and Nitrogen Fertilizer in Wheat Crop: I. Soil Water Content," Agronomy Journal, Vol. 99, No. 1, 2007, pp. 59-65. http://dx.doi.org/10.2134/agronj2006.0025

[28] V. Sip, P. Růžek, J. Chrpová, R. Vavera and H. Kusa, "The Effect of Tillage Practice, Input Level and Environment on the Grain Yield of Winter Wheat in the Czech Republic," Field Crops Research, Vol. 113, No. 2, 2009, pp. 131-137. http://dx.doi.org/10.1016/j.fcr.2009.04.013

[29] Z. Su, J. Zhang, W. Wua, D. Cai, J. Lv, G. Jiang, J. Huang, J. Gao, R. Hartmann and D. Gabriels, "Effects of Conservation Tillage Practices on Winter Wheat WaterUse Efficiency and Crop Yield on the Loess Plateau, China," Agricultural Water Management, Vol. 87, No. 3, 2007, pp. 307-314. http://dx.doi.org/10.1016/j.agwat.2006.08.005

[30] N. L. Morris, P. C. H. Miller, J. H. Orson and R. J. Froud-Williams, "The Effect of Wheat Straw Residue on the Emergence and Early Growth of Sugar Beet (Beta vulgaris) and Oilseed Rape (Brassica napus)," European Journal of Agronomy, Vol. 30, No. 3, 2009, pp. 151-162. http://dx.doi.org/10.1016/j.eja.2008.09.002

[31] S. Tessier, K. E. Saxton, R. I. Papendick and G. M. Hyde, "Zero-Tillage Furrow Opener Effects on Seed Environment and Wheat Emergence," Soil and Tillage Research, Vol. 21, No. 3-4, 1991, pp. 347-360. http://dx.doi.org/10.1016/0167-1987(91)90030-2

[32] A. I. Cociu and E. Alionte, "Yield and Some Quality Traits of Winter Wheat, Maize and Soybean, Grown in Different Tillage and Deep Loosening Systems Aimed to Soil Conservation," Romanian Agricultural Research, Vol. 28, No. 1, 2011, pp. 109-120.

[33] P. D. Vita, E. D. Paolo, G. Fecondo, N. D. Fonzo and M. Pisante, "No-Tillage and Conventional Tillage Effects on Durum Wheat Yield, Grain Quality and Soil Moisture Content in Southern Italy," Soil and Tillage Research, Vol. 92, No. 1-2, 2007, pp. 69-78. http://dx.doi.org/10.1016/j.still.2006.01.012

[34] D. R. Coventry, R. S. Poswal, A. Yadavc, R. K. Gupta, S. 
C. Gill, R. S. Chhokar, V. Kumard, R. K. Sharma, A. Kumar, A. Mehtae, S. G. L. Kleemanna and J. A. Cummins, "Effect of Tillage and Nutrient Management on Wheat Productivity and Quality in Haryana, India," Field Crops Research, Vol. 123, No. 3, 2011, pp. 234-240. http://dx.doi.org/10.1016/j.fcr.2011.05.016

[35] M. A. Khan, I. Hussain and M. S. Baloch, "Wheat Yield Potential Current Status and Future Strategies," Pakistan Journal of Biological Sciences, Vol. 3, No. 1, 2000, pp. 82-86. http://dx.doi.org/10.3923/pjbs.2000.82.86

[36] A. R. Tavakoli and T. Y. Oweis, "The Role of Supplemental Irrigation and Nitrogen in Producing Bread Wheat in the Highlands of Iran," Agricultural Water Management, Vol. 65, No. 3, 2004, pp. 225-236. http://dx.doi.org/10.1016/j.agwat.2003.09.001

[37] H. Hussain, M. A. Khan and E. A. Khan, "Bread Wheat Varieties as Influenced by Different Nitrogen Levels," Journal of Zhejiang University Science and Biology, Vol. 7, No. 1, 2006, pp. 70-78. http://dx.doi.org/10.1631/jzus.2006.B0070

[38] C. Kosmas, S. Gerontidis, M. Marathianou, B. Detsis, T. Zafiriou, W. N. Muysen, G. Govers, T. Quinec and K.
Vanoost, "The Effects of Tillage Displaced Soil on Soil Properties and Wheat Biomass," Soil and Tillage Research, Vol. 58, No. 1-2, 2001, pp. 31-44. http://dx.doi.org/10.1016/S0167-1987(00)00175-6

[39] E. A. Warraich, N. Ahmad, S. M. A. Basra and I. Afzal, "Effect of Nitrogen on Source-Sink Relationship in Wheat," International Journal of Agriculture and Biology, Vol. 4, No. 2, 2002, pp. 300-302.

[40] K. Jabran, Z. A. Cheema, M. Farooq, S. M. A. Basra, M. Hussain and H. Rehman, "Tank Mixing of Allelopathic Crop Water Extracts with Pendimethalin Helps in the Management of Weeds in Canola (Brassica napus) Field," International Journal of Agriculture and Biology, Vol. 10, No. 3, 2008, pp. 293-296.

[41] O. Erenstein, K. Sayre, P. Wall, J. Dixon and J. Hellin, "Adapting No-Tillage Agriculture to the Conditions of Smallholder Maize and Wheat Farmers in the Tropics and Sub-Tropics," In: T. Goddard, M. Zoebisch, Y. Gan, W. Ellis, A. Watson and S. Sombatpanit, Eds., No-Till Farming Systems, Special Publication 3, World Association of Soil and Water Conservation (WASWC), Bangkok, 2008, pp. 253-278. 